DOI: $10.26693 / \mathrm{jmbs} 05.05 .376$

UDC 612.3-057.874=111

Beghalia Mohamed ${ }^{1}$, Nacer Abdelkader ${ }^{2}$, Boufaden Othmane ${ }^{3}$, Belghrissi Abdelhamid'

\title{
Analysis of Somatotype of Schoolchildren aged 12 to 15 years old and their Nutrition Behavior
}

\author{
${ }^{1}$ University Centre of Tissemsilet, Algeria \\ ${ }^{2}$ University Abd Hamid Ibn Badis, (STAPS) Mostaganem, Algeria \\ ${ }^{3}$ University Mohamed Boudiaf (STAPS) Oran, Algeria
}

beghaliamohamed@ymail.com

The stage of adolescence is the stage in which the young person's life is affected by physiological factors influencing their activity and their personality clearly. The characteristics of adolescence differ because of many factors, including individual genetics, climate and nature. Physical growth at this stage is characterized by speed with imbalance where the body grows very quickly and inconsistently. This stage is characterized by the change in the growth of height and weight, and the effect of this is reflected in the breadth of the shoulders and the chest, the length of the trunk, the circumference of the buttocks and the length of the legs, and the physical growth reaches its maximum speed at the age of 12 years for girls and the 14 years for boys.

Material and methods. This study includes the age group 12-15 of the school's students. The study was conducted on a sample of about 70 pupils who were randomly selected, 32 of whom were girls and 38 boys from the total sample of the school's total number of 355 students. We used anthropometric measurements through which we extracted the percentage of body masses as well as determined body patterns. In order to determine the effect of feeding, we monitored the nutritional behavior of the research sample for a month and recorded the contents of the meal (breakfast, lunch and dinner for the last day plus other random times).

Results and discussion. The study showed that muscle mass was proportional to its eating behavior. Muscle mass is the predominant sample for both sexes. Its percentage is the highest among other ratios, as it was confined between $42.25 \%$ and $56.03 \%$, followed by bone mass by $20.53 \%$ and $25.19 \%$, and finally fat mass by $8.29 \%$ and $11.01 \%$, respectively. The results showed that the amounts of substances rich in carbohydrates were those that govern the daily diet. The average meal during a month was estimated at $84.75 \%$ through eating large quantities of bread, couscous and pasta. Both height and weight were in direct proportion to age, and by tracking the growth path from the age of 06 to 15 years, the proportion of both cholesterol and triglycerides were proportional. With the mass ratio, the cholesterol ratio in the blood was estimated to be between [1.09-1.58] $\mathrm{g} / \mathrm{I}$, and the triglyceride ratio was between [0.78-1.02] $\mathrm{g} / \mathrm{l}$.

Conclusion. Having analyzed and discussed the results, and similar studies, we concluded that muscle mass was the dominant one for the research sample on the bone and fat masses.

Keywords: somatotype, nutrition, anthropometric, schoolchildren.

Introduction. The changes in the somatotype components during growth in adolescents between 10 and 19 years can provide vital information for growth patterns, the timing, and rate of sexual maturation [1]. Somatotype is a taxonomy that allows the interpretation of a body structure based on different elements [2]. The somatotype corresponds to the estimation of the corporeal shape and its composition, which is expressed in three numbers that correspond to the components obtained during the embryological development: endoderm, mesoderm and ectoderm, altogether corresponding to the morphological characteristics of the subject as a whole [3]. A study analyzed anthropometric characteristics and somatotype of young players at different ages (14-18 years) from teams of the First Macedonian league $(n=486)$ and compared the results with data from general population. Obtaining players at 14 years showed significant lower values of muscle and fat mass. They also discovered that in all age soccer groups mesomorph component of the somatotype dominated. Furthermore, athletes presented smaller values of the fat and endomorphic component and greater muscle and mesomorph component in comparison with general population [4].

The growth pattern is influenced by many factors such as nutritional status, socioeconomic conditions and environmental and genetic factors. The survey was conducted among the agricultural population of the hilly areas of the districts; therefore, their underprivileged backgrounds could be one of the main factors which could have contributed to the shunting in their height and weight [5]. The boys are more athletic especially for the age 13-14 years old in comparison to the girls where endomorphic somatotype is predominant for both age groups as they have more 
developed adipose tissue, but less developed muscle mass [6]. We have somatotyped children of a residential rural school in Pondicherry. We observed that somatotype of girls and boys were significantly different. Endomorph physique was more in girls, while mesomorph and ectomorph physique was dominant in boys [7]. The boys are more athletic especially for the age 13-14 years old in comparison to the girls where endomorphic somatotype is predominant for both age groups because they have more developed adipose tissue, but less developed muscle mass [6]. The lightest categories were recognized as mesomorph ectomorphs in females with an exception in the $48 \mathrm{~kg}$ category, and ectomorph mesomorphs in male athletes. The middle ones had the endomorphic mesomorph somatotype and the heaviest athletes presented somewhat more extreme cases of endomorphic mesomorphs, both in male and female judokas. According to the results obtained, judokas have a specific body composition in different weight categories. Therefore, coaches could create a specific training program for athletes who belong to different somatotypes [8]. To examine one, until now, not investigated issue, to assess the impact of some socioeconomic factors on somatotype components of the population group of adolescents of both males and females in the Republic of Macedonia. According to our study socioeconomic factors are related to somatotype components, especially with endomorph and mesomorph component of somatotype of Macedonian adolescents. We can conclude that parents' educational level and employment status had some influence on body shape and composition. When determining the somatotype of Macedonian adolescents socioeconomic inequalities and sex should be considered [9].

Today, it is very important to teach the child to take care of their own health while studying at school and to develop an attitude for maintenance of their health status without the use of medicines. To improve the health status and the level of physical activity of students, in addition to attending physical education classes, it is necessary to use recreational forms of physical education and implement healthdeveloping technologies, which include execution of gymnastic exercises before the classes and within the classes, physical exercises and active games during long breaks between classes, daily exercises in prolonged-day groups, individual physical exercises during out-of-school time, physical activities at the place of residence, etc. [10].

The purpose of the research was to determine somatotype of schoolchildren aged from 12-15 years old and to analyze their nutritional behavior.

Material and methods. Heath and Carter anthropometric somatotype come to this method using measurements anthropometry and is a method commonly used for accuracy and objectivity. Furthermore, it does not use photography, which can be expensive for some people [2]. We used Heath Carter to reach the following equations and to calculate the three components of the pattern of the body (fat, muscle, thin) using metric units. We accounted astvia using the following corrections:

1. Measure the height $(\mathrm{cm})$.

2. Measurement of weight $(\mathrm{kg})$.

3. Extract the average height weight (HWR) of the following equation: H.W.R = Height / Weight using the geometric shape of average height and weight "measurement systems".

4. Measurements of the thickness of skin folds of the following thickness of the skin fold behind the upper arm (mm) [11].

We divided the body into five regions:

1. The first area: the head and neck.

2. Region II: the chest or trunk above the diaphragm.

3. Region III: arms and hands arms and hands.

4. Region IV: abdominal or trunk below the diaphragm.

5. Fifth District: legs and feet.

Then the evolution of the order and using a new method called the method of measurement metric imaging Photogrammetric Technique.

1. Photography of the body from the front and side and rear in a manner known as Sheldon.

2. Use the form to the discretion of each sector in the light. Regions and categories of card style body: Card style body diagram represents the five identifying places where the objects and patterns of spread of the sample under measurement, and is divided into thirteen segments of a watershed. A card-style has three axes, each representing one of the three components of the body muscle and obesity [12].

3. We published the same work in 2019 with the age 6-12 years, this study is the same in its methodology, but the age is $12-15$ years, adding this time if the effect of the nutritional environment. We continued to carry out various anthropometric measurements on the sample, and the difference between men and women in the components of the pattern they have. We also defined the relationship between each of blocks of bone and fat muscle mass.

Results. The study of each measurement of height and weight of the research sample is one of the main indicators of the growth process. Table 1 reveals the process of increasing the length measurement was in line with the progress in life as the length measurement increases gradually with ages.

The study of both the measurement of height and weight of the research sample is one of the main indicators of the growth process. Table 1 reveals that 
Table 1 - The results of measuring height and weight of schoolchildren aged the weight was $31 \mathrm{~kg}$, while the 12-15 years

\begin{tabular}{|c|c|c|c|c|c|c|c|c|}
\hline \multirow{2}{*}{ Gender } & \multirow{2}{*}{ Age } & The rest & \multicolumn{2}{|c|}{ Bone mass } & \multicolumn{2}{c|}{ Muscle mass } & \multicolumn{2}{c|}{ Adipose mass } \\
\cline { 3 - 9 } & & $\%$ & $\%$ & kg & $\%$ & kg & $\%$ & kg \\
\hline \multirow{4}{*}{ Boys } & 12 & $22.80 \%$ & $24 \%$ & 7.44 & $42.25 \%$ & 13.09 & $10.93 \%$ & 3.39 \\
\cline { 2 - 9 } & 13 & $22 \%$ & $24.25 \%$ & 8.49 & $42.77 \%$ & 14.97 & $10.97 \%$ & 3.84 \\
\cline { 2 - 9 } & 14 & $16.90 \%$ & $25.19 \%$ & 9.7 & $47.76 \%$ & 18.39 & $10.12 \%$ & 3.9 \\
\cline { 2 - 9 } & 15 & $19.15 \%$ & $23.93 \%$ & 10.02 & $46.11 \%$ & 19.31 & $10.79 \%$ & 4.52 \\
\hline \multirow{3}{*}{ Girls } & 12 & $15.89 \%$ & $22.17 \%$ & 7.38 & $53.63 \%$ & 17.85 & $8.29 \%$ & 2.76 \\
\cline { 2 - 9 } & 13 & $9.67 \%$ & $24.64 \%$ & 7.64 & $56.03 \%$ & 17.37 & $9.64 \%$ & 2.99 \\
\cline { 2 - 9 } & 14 & $19.44 \%$ & $20.85 \%$ & 8.46 & $48.70 \%$ & 19.76 & $10.99 \%$ & 4.46 \\
\cline { 2 - 9 } & 15 & $16.67 \%$ & $20.53 \%$ & 9.36 & $51.76 \%$ & 23.59 & $11.01 \%$ & 5.02 \\
\hline
\end{tabular}
13-year-old category was an average length of $149.5 \mathrm{~cm}$, while the average weight was $35 \mathrm{~kg}$ with a difference of 8.63 $\mathrm{cm}$ in length and $4 \mathrm{~kg}$ in weight.

Table 2 presents the measurement of the body masses of the research sample.

The muscle mass represents the largest part of the total body weight, as it reached $13.09 \mathrm{~kg}$ in the male 12-year category, to ascend by $14.97 \mathrm{~kg}$ the process of increasing the length measurement was in line with the progress in life as the length measurement increases gradually with ages. Through the results shown in table 1 , the average height for a 12-year-old male category was $140.87 \mathrm{~cm}$, while at the 13-year age category and keep on escalating to reach 18.39 and $31.19 \mathrm{~kg}$ in the $14-15$ years category, respectively. This is what refers to with an increase in muscle mass at the expense of the bone mass where there is significant growth in the bones.

Table 2 - The components of the masses of schoolchildren aged 12-15 years

\begin{tabular}{|c|c|c|c|c|c|c|c|c|c|c|c|c|c|}
\hline \multirow{2}{*}{\multicolumn{2}{|c|}{$\begin{array}{c}\text { Age } \\
\text { Statistics }\end{array}$}} & \multicolumn{3}{|c|}{15 years } & \multicolumn{3}{|c|}{14 years } & \multicolumn{3}{|c|}{13 years } & \multicolumn{3}{|c|}{12 years } \\
\hline & & 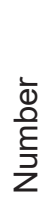 & 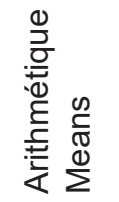 & $\begin{array}{l}\frac{\pi}{\pi} \\
\frac{0}{0} \\
\frac{\pi}{0} \\
\dot{\omega}\end{array}$ & 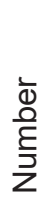 & 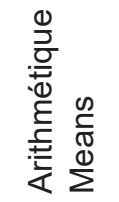 & $\begin{array}{l}\frac{\pi}{\pi} \\
\frac{0}{0} \\
\frac{\pi}{\pi} \\
\text { ஸे }\end{array}$ & 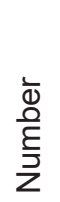 & 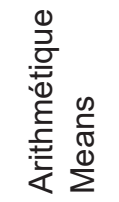 & 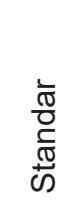 & 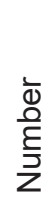 & 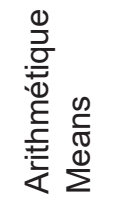 & 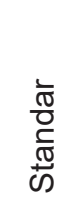 \\
\hline \multirow{2}{*}{ Boys } & Length, cm & 9 & 157.75 & 6.58 & 9 & 154 & 5.65 & 13 & 149.5 & 4.32 & 9 & 140.87 & 7.88 \\
\hline & Weigh, kg & 9 & 41.87 & 6.83 & 9 & 38.5 & 4.07 & 13 & 35 & 4.44 & 9 & 31 & 4.03 \\
\hline \multirow{2}{*}{ Girls } & Length, $\mathrm{cm}$ & 8 & 156.02 & 3.38 & 8 & 154.95 & 8.12 & 8 & 148.35 & 6.35 & 8 & 145.07 & 5.16 \\
\hline & Weight, kg & 8 & 45.57 & 5.99 & 8 & 40.57 & 7.65 & 8 & 31 & 2 & 8 & 33.28 & 3.25 \\
\hline
\end{tabular}

The bone mass of $7.44 \mathrm{~kg}$ at the 12-year age began to rise gradually, reaching $8.49 \mathrm{~kg}$ and $9.7 \mathrm{~kg}$ in the 13.14 years, respectively with less than the muscle and bone masses, the fat mass in males was estimated to be $3.39 \mathrm{~kg}$ at the age of 12 years, began to gradually rise to $3.84 .3 .9 \mathrm{~kg}$ at the age of $13-14$ years, respectively, to reach $4.52 \mathrm{~kg}$ at the age of 15 years (Table 3 ).

Figure1 represents the measurement of the body masses of the research sample. The muscle mass represents the largest part of the total body weight, as

Table 3 - The identification of body patterns of schoolchildren aged 12-15 years

\begin{tabular}{|c|c|c|c|c|c|}
\hline Type & $\begin{array}{c}\text { Obesity } \\
\text { component }\end{array}$ & $\begin{array}{c}\text { Muscle } \\
\text { component }\end{array}$ & $\begin{array}{l}\text { Component } \\
\text { of thinness }\end{array}$ & Age & Gender \\
\hline Slim muscular & 1 & 5.5 & 4.5 & 12 & \multirow{4}{*}{ Girls } \\
\hline Muscular slim & 1.5 & 5 & 6 & 13 & \\
\hline Slim muscular & 1 & 5 & 4.5 & 14 & \\
\hline Slim muscular & 1.5 & 6 & 3 & 15 & \\
\hline Slim muscular & 1.5 & 6 & 4 & 12 & \multirow{4}{*}{ Boys } \\
\hline Slim muscular & 2 & 5.5 & 5 & 13 & \\
\hline Slim muscular & 1.5 & 5.5 & 5 & 14 & \\
\hline Slim muscular & 2 & 5 & 4.5 & 15 & \\
\hline
\end{tabular}

it reached $13.09 \mathrm{~kg}$ in the male 12-year category, to ascend by $14.97 \mathrm{~kg}$ at the 13-year age category and keep upward to reach 18.39 and $31.19 \mathrm{~kg}$ in the $14-15$ years category, respectively. The increase in muscle mass at the expense of the bone mass, where there is significant growth in the bones.

Obesity component. The rate of obesity in males was estimated at 1.5 in the 12-year category, to ascend to 2 , and then went down to 1.5 in the 1314-year age groups, respectively, to settle at 2 in the 15 years. As for females, the rate of obesity had 1 at the age of 12 years, to ascend to a value of 1.5 at the age of 13 years, then it fell at the age of 14 years, where it was estimated at 1 , and it stabilized at the age of 15 years at a rate of 1.5. Table 3 showed that the obesity value was confined between [1-2] males and females, and this corresponds to the percentage of lipid mass for the research sample. The lipid mass ratio is 10.34 percent, which is the lowest compared to the bone and muscle masses. 
Muscle component. The average muscle rate for males was 6 at the 12-year age group and 5.5 at the $13-14$ year-old age group, reaching 5 at 15 years. As for females, their muscle rate was 5.5 in the 12-year age group and 5 in the 13-14-year age group, to ascend to 6 in the 15year age group. At this stage, the physical proportions were moderate, and they became close to similarities with the adult, where the limbs are connected and the bones are larger than before.

Thinness component. The thinnest component of males reached 4 , to ascend to 5 in the 13-14 age group, decreasing to 4.5 in the 15 -year old group. As for females, the rate of thinness was 4.5 in the 12-year category, to ascend to 6 in the 13-year group, and then it decreased to 4.5 in the 14 -year age group, to went down to 3 in the 15-year age group, and from here we saw that the thinness component was confined between [3-6] for both sexes and this was due to a lack of lipids in the research sample.

By analyzing the results recorded in Table 3 we concluded that the dominant pattern in both males and females of all ages was muscular and thin (Figures 2,3 ). This indicates the control of the muscle mass at this stage.

Table 4 showed that the quantities of carbohydrate-rich substances were the ones that control the daily diet approved for the research sample, where the average meal during a month in males was estimated at $72.75+$ through eating bread, couscous and pasta in abundance, and fatty substances may be scarce and may be non-existent. Occasionally, the proportion

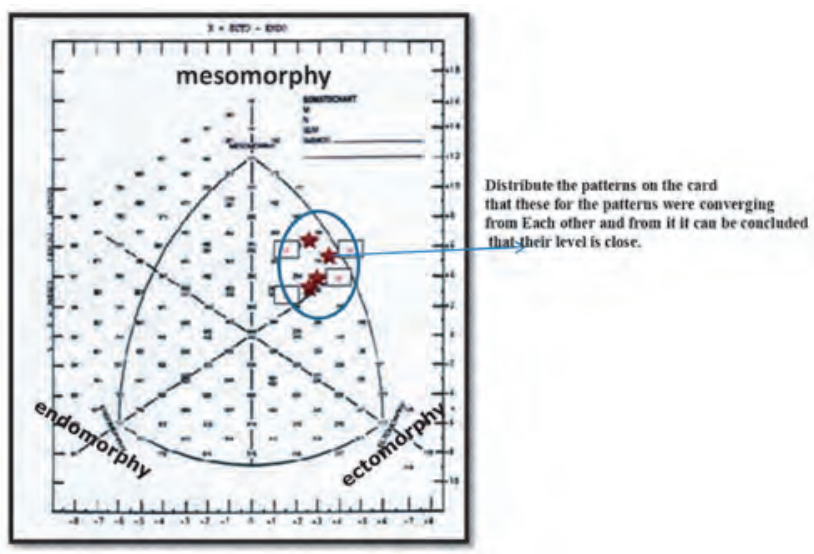

Figure 2. The distribution of body styles on the style card of schoolchildren aged 12-15 years of protein sources was scarce and not varied, as the average intake of foods rich in proteins such as meat and eggs reached 29.5+ in males. As for females, it may also be noted that starchy rich materials dominated the approved daily diet with an arithmetic average of $84.75+$ and This is due to the fact that they eat bread, couscous and pasta in abundance, and there is a shortage of protein sources, where the average meal is estimated during a month in females by eating meat and eggs at $33.5+$, and it is also noticed that not eating foods rich in fat (meat of all kinds, dairy, derivatives Milk), where we see that the rate of consuming milk derivatives for males and females is $24+$, $28+$, respectively, and from here the researchers see that there is no nutritional balance for the research sample, because the quality and quantity of food are not consistent in one meal and are not available on

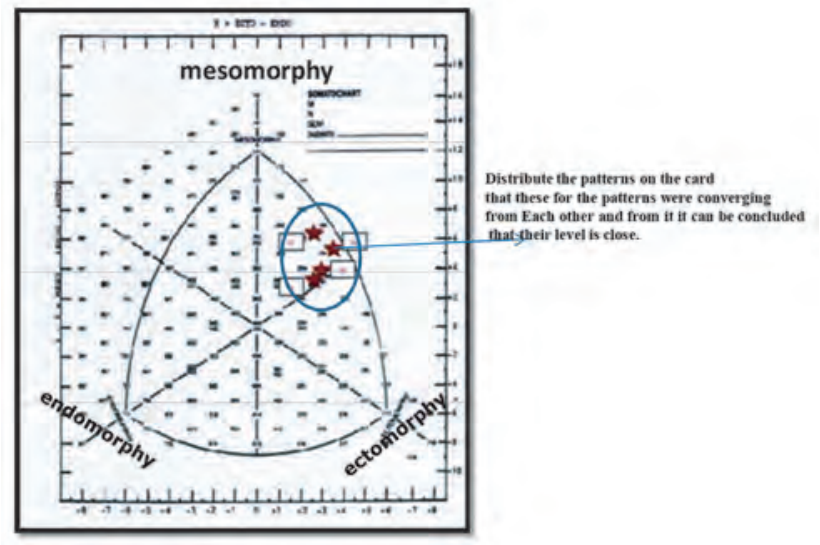

Figure 3. The distribution of body styles on the pattern card of schoolchildren aged 12-15 years 
nutrients. That allows for growth, maintenance, work or activity.

Food imbalance is the condition in which one feeds incorrectly, not only from eating very small amounts of food but rather from a mixture of factors: Eat insufficient amounts of proteins, energy-generating materials, micronutrients, infections or recurrent diseases, poor care and inadequate health services, unsecured water, using unhealthy eating habits and behaviors. This imbalance is represented by not consuming dairy (dairy products), meat and legumes group, vegetables and fruits group, grain group. Here are the main important values of these groups. Dairy is necessary to provide the body with protein, calcium, and vitamin $D$ to build muscle, bone, and teeth. Meat and legumes are necessary to provide the body with protein, iron, vitamin $B$, and some mineral elements, the most important of which are iron and zinc, all of which are necessary for the safety of bones and blood and to build muscle (growth). Grains are necessary to supply the body with vitamins "B" and iron, as well as fiber, and this group is the most important among the other groups as a source of energy. Vegetables provide vitamins and fiber in the first place. Fruits provide the body with vitamins, which are considered a good source of fiber.

And the research results [13] indicate that for both height and weight there is a clear indication of the growth of the individual as we note that the growth path of the research sample passes on three stages: 06-09 years, $13-13$ years, and $13-15$ years. It is noted that both height and weight are directly proportional to age. It is evident to us that they are growing in parallel and in close proportions in the stage of 06-09 years, as the average length for the 06-year category $(119.12,117.33) \mathrm{cm}$ for both sexes together and with an average weight of $(23.22,20.66) \mathrm{kg}$, respectively, to reach all the way up to $(134.6,135.1) \mathrm{cm}$ and with an average weight of $(31.11,29.33) \mathrm{kg}$. The second stage is confined between 9-13 years, in which the phenomenon of mutation in longitudinal growth occurs. It was evident in the research sample at the age of 11 and half that the males were delayed by about a year and a half of this age, i.e. at the age of 13 years. The difference in length between the ages of 11 and 12 years in females was about $08 \mathrm{~cm}$, while in males it reached $4.5 \mathrm{~cm}$. As for the average weight, the imbalance was evident, so that it remained between going up and down. The largest concession was from the 11-year to 12-year category in males where the difference was $-5.22 \mathrm{~kg}$, while for the females it was of the same two categories, as the difference reached $-1.28 \mathrm{~kg}$.

This imbalance is a result of fluctuations in the maturity of the different body systems, which are considered to be internal factors represented in the joint genetic programming of the process of physical maturity in the human species, as well as to environmental factors such as (food, diseases, and emotional atmosphere), as these factors play an important role in the diversity of speeds growth and the extent to which this growth reaches a certain age.

Finally, there is a stage between 13 and 15 years. Here is a gradual growth in growth for both height and weight. As the average weight for the 13-year category was $35 \mathrm{~kg}, 31 \mathrm{~kg}$ for both males and females, respectively, to ascend to $38.5,40.75 \mathrm{~kg}$ in the 14 -year category, while in the 15-year category. The average weight increased to 41.87 and $45.57 \mathrm{~kg}$ for both sexes, respectively. As this continuation of growth comes after an imbalance and fluctuation in growth due to several factors, the most important of which is sexual puberty (Table 5).

Discussion. The obtained results in the various anthropometric measurements and following the dietary pattern that was conducted on the research sample of the age group 12-15 years, and blood analyzes for the 12-year-old group, made the two researchers, after discussion and analysis, reach the following conclusion (Table 6, Figure 4). 
Muscle mass is the dominant one for the research sample for both sexes together, as it is noticed that its percentage is the highest among the other ratios as it is confined between [42.2556.03] \%, followed by the bone mass at a ratio between [20.53$25.19] \%$, and finally the mass comes lipid profile, ranging between [8.29-11.01]\%. Growth of body size (body height and body weight) and somatotype in 363 girls and 299 boys aged 4 to 20 years of ethnic Javanese lived in Magelang Regency Indonesia were studied cross-sectionally. Over half of them were categorized in the well-off family, therefore underweight or underfat prevalence in our subjects was low $(14.3 \%)$ but overweight and obesity prevalence was also low (14\%). They were shorter and lighter than reference children from U.S., Japan and Yogyakarta but they improved when compared with those of the same ethnic of Bantul and with the different ethnic of rural India. There was a clear age-related change of their somatotype [14].

The dominant pattern for the research sample is the lean muscular pattern for both males and females, because the muscle component results are predominant, followed by the thinness component to a lesser degree, while the obesity component is the least through the results obtained. Somatotype changes for 11 and 12 year-old adolescents and for the endomorphic somatotype is predominant, respectively 32 $(40 \%)$ and 34 (39.1\%). The greatest change in somatotype comes at the age of 14 . The biggest share here is for ectomorphic type -18 (48.6\%), and the smallest share is for endomorphic somatotype - 6 (16.2 \%) schoolchidren. The study established a statistically significant variance in both group age 11-12 and 13-14 somatotype, respectively for the boys ( $x 2=9.29$; $d f=2 ; p=0.01$ ), but there is no similar correlation for the girls $\left(x^{2}=0.65\right.$; $d f=$ 2; $p=0.72$ ) [6]. The three main components of the somatotype are endomorphic, which characterizes the relative development of adipose tissue; mesomor-

\begin{tabular}{|c|c|c|c|c|c|c|}
\hline Gender & $\begin{array}{l}\text { Standard } \\
\text { deviation } \\
\text { of weight }\end{array}$ & $\begin{array}{c}\text { Average } \\
\text { weight }\end{array}$ & $\begin{array}{l}\text { Standard } \\
\text { deviation } \\
\text { of length }\end{array}$ & $\begin{array}{l}\text { Average } \\
\text { of length }\end{array}$ & $\begin{array}{c}\text { Number } \\
\text { of sample }\end{array}$ & $\begin{array}{c}\text { The } \\
\text { sample }\end{array}$ \\
\hline \multirow{10}{*}{ Boys } & 4.32 & 23.22 & 3.57 & 119.22 & 09 & 06 \\
\hline & 2.87 & 23.33 & 4.07 & 121.11 & 09 & 07 \\
\hline & 1.93 & 26.33 & 4.23 & 126.7 & 09 & 08 \\
\hline & 2.52 & 31.11 & 3.74 & 134.6 & 09 & 09 \\
\hline & 5.19 & 35 & 5.134 & 143.11 & 09 & 10 \\
\hline & 3.96 & 36.22 & 8.07 & 144.44 & 09 & 11 \\
\hline & 4.03 & 31 & 7.88 & 140.87 & 09 & 12 \\
\hline & 4.44 & 35 & 4.32 & 149.5 & 13 & 13 \\
\hline & 4.07 & 38.5 & 5.65 & 154 & 09 & 14 \\
\hline & 6.83 & 41.87 & 6.58 & 157.75 & 09 & 15 \\
\hline \multirow{10}{*}{ Girls } & 1.36 & 20.66 & 4.17 & 117.33 & 09 & 06 \\
\hline & 5.91 & 23.83 & 4.96 & 122.5 & 09 & 07 \\
\hline & 3.44 & 22.66 & 5.29 & 125 & 09 & 08 \\
\hline & 3.88 & 29.33 & 6.46 & 135.1 & 09 & 09 \\
\hline & 4.85 & 29 & 5.92 & 135.3 & 09 & 10 \\
\hline & 3.61 & 34 & 4.92 & 137.5 & 09 & 11 \\
\hline & 3.25 & 33.28 & 5.16 & 145.07 & 08 & 12 \\
\hline & 2 & 31 & 6.35 & 148.35 & 08 & 13 \\
\hline & 7.65 & 40.57 & 8.12 & 154.95 & 08 & 14 \\
\hline & 5.99 & 45.57 & 3.38 & 156.02 & 08 & 15 \\
\hline
\end{tabular}

Table 6 - The indicators of blood analysis (blood sugar, cholesterol, triglycerides) of 12 year-old schoolchildren

\begin{tabular}{|c|c|c|c|c|}
\hline Gender & Triglycerides g/l & Cholesterol g/l & Glycemic g/l & Samples \\
\hline \multirow{4}{*}{ Boys } & 0.85 & 1.31 & 0.86 & 1 \\
\cline { 2 - 5 } & 1.02 & 1.19 & 0.92 & 2 \\
\cline { 2 - 5 } & 1.57 & 1.15 & 0.96 & 3 \\
\cline { 2 - 5 } & 0.80 & 1.35 & 0.80 & 4 \\
\cline { 2 - 5 } & 1.40 & 1.33 & 1.20 & 5 \\
\hline \multirow{4}{*}{ Girls } & 0.85 & 1.15 & 0.67 & 6 \\
\cline { 2 - 5 } & 1.23 & 1.58 & 0.84 & 7 \\
\cline { 2 - 5 } & 1.09 & 1.41 & 0.73 & 8 \\
\cline { 2 - 5 } & 0.90 & 1.10 & 0.87 & 9 \\
\cline { 2 - 5 } & 0.78 & 1.37 & 0.89 & 10 \\
\cline { 2 - 5 } & 1.00 & 1.09 & 0.80 & 11 \\
\hline
\end{tabular}

phic, which characterizes the relative musculoskeletal development; and ectomorphic component characterizing the relative linearity of the body. The human somatotype is defined depending on which component predominates among the three [15].

There was a lack of a nutritional balance for the research sample due to malnutrition and inconsistent diet. Food rich in starch is predominant and food rich in fat and protein is less. It is currently important to be able to establish logical plans for physical work and/ or nutrition aimed at achieving optimal levels of performance and wellbeing. To achieve this, it is crucial 
to understand anthropometric data and how they relate to body type and, above all, how they associate with parameters linked to health.

The present study, therefore, proposed to examine intersexual morphological differences and to determine the existing relationship between somatotype and BMI in a sample of school sports players from Huacho (Peru). A descriptive, comparative, correlational, and transversal study was delivered within a sample of 294 students (165 males and 129 females). Participants were aged between 12-15 years and regularly participated in team sports at

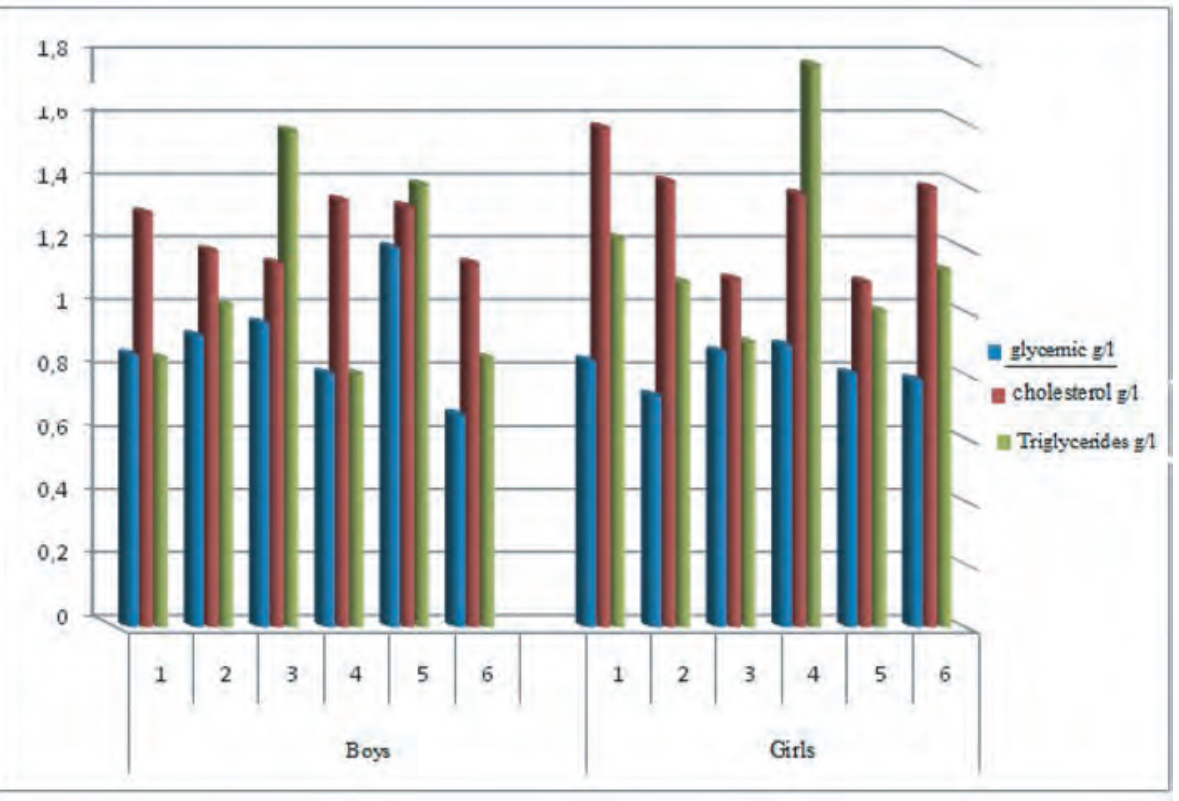

Figure 4. The indicators of blood tests for the research sample competitive school level. All participants took part in the anthropometric examination in order to determine their somatotype and body mass index. Significant differences were found to exist between the sexes in practically all of the anthropometric measures. The data demonstrated a high index of overweight and obesity. Further, the zones of occupation of the somatochart for both populations showed a displacement towards endomorphism, and that the level of typological similarity between populations was $30.54 \%$. Results indicated a serious need for training so that adolescent students acquire healthy habits and lifestyles [16].

The nutritional pattern of the research sample commensurated with the proportions of body masses, as the lack of intake of fat-rich foods led to a decrease in the lipid mass of the research sample, and the failure to eat both proteins and fats in sufficient quantities led to a slowdown in the growth of muscle mass. Malnutrition is still prevalent globally with the coexistence of both over nutrition and under nutrition in developing countries affecting people of all ages [17]. Adolescents are particularly at risk of malnutrition due to rapid growth and development and changes in dietary habits that may have influenced their nutrient intake [18]. Diet of adolescents in boarding secondary schools is monotonous comprising mainly of cereals and legumes with minimal animal sources, fruits, and vegetables which are important in the provision of key micronutrients. Moreover, boarding school diet is inadequate in essential micronutrients of iron, zinc, calcium, and vitamin C based on adolescents' Recommended Daily Allowance according to age and sex [19]. This study was conducted to determine nutritional status and associated factors among school

adolescent girls in Awash town. The main nutritional problem which affects adolescents is under nutrition in terms of stunting and thinness. This study revealed a prevalence of thinness and stunting of $8.82 \%$ and $22.9 \%$, respectively [20].

Both height and weight are in direct proportion to age, by tracking the path of growth from the age of 06 to 15 years, we have observed the growth stage divided into three stages as follows:

1- [06-09] years: both height and weight grow in parallel and in close proportion;

2- [09-13] years: the phenomenon of boom in longitudinal growth, and an imbalance in weight;

3- [13-15] years: continuing to grow steadily after a period of imbalance and fluctuation.

The mean height and weight values for gymnasts increased progressively from the age of $7.2 \pm 0.3$ until they began to stabilize at the age of $19.1 \pm 0.3$ (height: $170.1 \pm 5 \mathrm{~cm}$; weight: $64.2 \pm 4.3 \mathrm{~kg}$.) Significant differences in height were found $(p \leq 0.05)$ between the ages of $12.1 \pm 0.4$ and $15.1 \pm 0.2$, and in weight between the ages of $14.3 \pm 0.5$ and $16.1 \pm 0.3$. Across all ages the mean height value for gymnasts was lower than that of the reference sample, with significant differences between the ages of $10.2 \pm 0.4$ and $12.1 \pm 0.4$ ( $p \leq 0.05)$, and $14.3 \pm 0.5$ and $18.1 \pm 0.4$ ( $p \leq 0.001$.) The weight results followed a similar trend, except between the ages of $9.1 \pm 0.4$ and $12.1 \pm 0.4$ where significantly lower values were observed $(p \leq 0.05)$ compared with those of the refer [21]. The study results also showed that the body dimensions of adolescent girls increase primarily in relation to sexual maturation. These changes occur late in the sequence of changes associated with sexual maturation. The mean age at menarche varies from one setting to another and is known to be a sensitive indicator of various 
characteristics of a population including socio-economic status, nutritional status, geographical location and environmental conditions [22].

The ratios of both cholesterol and triglycerides are proportional to the lipid mass ratio of the research sample. Where the proportion of cholesterol in the blood was restricted between [1.09-1.58] g/l, and the ratio of triglycerides was restricted between [0.781.02] $\mathrm{g} / \mathrm{l}$, which are normal ratios that did not expose the research sample to the risk of diseases. Since the American Heart Association last presented nutrition guidelines for children, significant changes have occurred in the prevalence of cardiovascular risk factors and nutrition behaviors in children. Overweight has increased, whereas saturated fat and cholesterol intake have decreased, at least as percentage of total caloric intake. Better understanding of children's cardiovascular risk status and current diet is available from national survey data [23]. As children grow up, sources of food and influences on eating behavior increase. Social constraints on families may necessitate the presence of multiple caregivers, eating out, and frequent fast food consumption. Many children, because of parental work schedules, are home alone and prepare their own snacks and meals. By early adolescence, peer pressure begins to usurp parental authority, and fad diets may be initiated. Many meals and snacks are routinely obtained outside the home, often without supervision. Sites include schools, friends' homes, child-care centers, and social events. Older children have discretionary funds to use for selfselected foods. Current eating patterns do not at all resemble the "norm" of providing at least breakfast, dinner, and a single snack at home with lunch carried to school or purchased from a health-conscious cafeteria. For example, current diet studies suggest that many children do not eat breakfast and get at least one third of calories from snacks. Sweetened beverage intakes contribute significantly to total caloric intake [24].

Conclusion and prospects of further research. Through the analysis and discussion of the results, and through what was mentioned in the theoretical side, as well as similar studies, we concluded that muscle mass is the dominant one for the research sample on the bone and fat masses. A lean muscle pattern is also dominant among the research sample, and these two factors were detected after a set of anthropometric measurements. Changes in height, weight, and body masses from the age of 06 to 15 years of growth go through three different stages, which are as follows:

1- [06-09] years: both height and weight grow in parallel and in close proportions;

2- [09-13] years: the phenomenon of boom in longitudinal growth, and an imbalance in weight;

3- [13-15] years: continuing to grow steadily after a period of imbalance and fluctuation.

And through this research, the nutritional behavior of the research sample was known for a month with careful daily follow-up, which led to the lack of a nutritional balance, as it was found that the amount of nutrients consumed by the sample is proportional to its body mass. To further emphasize the findings, the nutritional behavior was used as well as blood tests for the 12-year-old group, which showed a clear proportion of blood lipids with lipid mass for this group, how far they were shown to be far from diseases such as diabetes, blood pressure and others. From here, the implications of both the chronological age and nutrition on the physical patterns of the research sample were revealed and are explained in detail in the presentation and discussion of the results shown in the previous tables and graphs.

\section{References}

1. Toselli S, Graziani F, Gruppioni G. Relationship Between Somatotype and Blood Pressure in Children Aged 6 to 14 Years. Acta Medicine Auxology. 1997; 29: 143-148.

2. Carter JEL, Heath BH. Somatotyping. Development and Applications. Cambridge: Cambridge University Press; 1990. 503 p.

3. Carter L. Somatotipo. In: Norton K, Olds T, Eds. Antropometrica. Marrickville, Sidney: Southwood Press; 1996. $273 \mathrm{p}$.

4. Gontarev S, Kalac R, Zivkovic V, Ameti V, Redjepi A. Anthropometrical charac-teristics and somatotype of young Macedonian soccer players. Int J Morphol.2016; 34(1): 160-7.

5. Jaiswal A, Elayaraja M. Investigation of Somatotyping in 6 to 14 year old boys of Chandauli and Mirzapur Districts of Uttar Pradesh - A Pilot Survey. J Human Biology Review. 2015; 4(2): 150-158.

6. Merdzhanova E, Petrova G, Lalova V. Analysis of adolescents' (11-14 years old) somatotype in plovdiv, Bulgaria. $J$ of IMAB. 2020 Jan-Mar; 26(1): 3005-3010.

7. Subramanian SK, Vivek Kumar S, Vinayathan A, Krishnakumar R, Rajendran R. Somatotyping in Adolescents: Stratified by Sex and Physical Activity. Int J Anat Appl Physiol. 2016; 2(3): 32-38.

8. Roklicer R, Atanasov D, Sadri F, Jahic D, Bojanic D, Ljubojevic M, et al. Somatotype of male and female judokas according to weight categories. Biomedical Human Kinetics. 2020; 12: 34-40. doi: 10.2478/bhk-2020-0005

9. Bojadzieva Stojanoska B. Impact of socioeconomic factors on somatotype components in macedonian adolescents. MOJ Anat Physiol. 2016; 2(4): 94-99. doi: 10.15406/mojap.2016.02.00050 
10. Andrieieva $\mathrm{O}$, Hakman A. Health status and morbidity of children 11-14 years of age during school. Journal of Physical Education and Sport ${ }^{\circledR}$ (JPES). 2018; 18(2): 1231-1236.

11. Hassanein MS. Atlas classification and characterization of patterns of objects first edition. Cairo; 1998. p. 210, 219, 220, 223.

12. Hassanein MS. Patterns of objects athletes of both sexes. House edition of the Arab Thought. $1995 ; 11: 113$.

13. Beghalia Mohamed, Nacer Abdelkader, Boufaden Othmane, Belghrissi Abdelhamid. Somatotype in 6-12-yearold West of Algeria Primary Schoolchildren. Ukraninian journal of medicine, biology and sport. 2019; 4(21): 353-359. doi: 10.26693/jmbs04.05.353

14. Widiyani T, Suryobroto B, Budiarti S, Hartana A. The Growth of Body Size and Somatotype of Javanese Children Age 4 to 20 Years. Journal of Biosciences. 2011 Dec; 18(4): 182-192.

15. Subramanian SK, Sharma VK, Rajendran R. Assessment of heart rate variability for different somatotype category among adolescents. J Basic Clin Physiol Pharmacol. 2018 Nov 13; 30(3): /j/jbcpp.2019.30.issue-3/ jbcpp-2018-0104/jbcpp-2018-0104.xml. doi: 10.1515/jbcpp-2018-0104

16. Linares-Manrique M, Hernández-Gallardo D, Arencibia-Moreno R, Rojas-Cabrera M, Macedo-Figueroa J, Linares-Girela D. Somatotype, BMI, and Sexual Dimorphism in Adolescent School Sports Players in Peru. Sustainability. 2019; 11(22): 6224.

17. FAO. The state of food and agriculture, 2013. Lancet, 2013; 2(7929): 313-314.

18. Christian P, Smith ER. Adolescent undernutrition: global burden, physiology, and nutritional risks. Annals of Nutrition and Metabolism. 2018; 72(4): 316-328.

19. Nicholaus C, Martin HD, Kassim N, Matemu AO, Kimiywe J. Dietary Practices, Nutrient Adequacy, and Nutrition Status among Adolescents in Boarding High Schools in the Kilimanjaro Region, Tanzania. J Nutr Metab. 2020 Jun; 2020: 3592813. doi: 10.1155/2020/3592813

20. Kahssay M, Mohamed L, Gebre A. Nutritional Status of School Going Adolescent Girls in Awash Town, Afar Region, Ethiopia. Journal of Environmental and Public Health. 2020; 2020: 7367139. doi: 10.1155/2020/7367139

21. Amigóa AI, Faciabéna AB, Evrarda MM, Ballarini PAG, Marginetc MC. Height, weight, somatotype and body composition in elite Spanish gymnasts from childhood to adulthood. Apunts med sport. 2009; 161: 18-28.

22. Al-Awadhi N, Al-Kandari N, Al-Hasan T, AlMurjan D, Ali S, Al-Taiar A. Age at menarche and its relationship to body mass index among adolescent girls in Kuwait. BMC Public Health. 2013 Jan 12; 13: 29. doi: 10.1186/14712458-13-29

23. Gidding SS, Dennison BA, Birch LL, Daniels SR, Gillman MW, Lichtenstein AH, et al. Dietary Recommendations for Children and AdolescentsA Guide for Practitioners: Consensus Statement From the American Heart Association. Circulation. 2005 Sep 27; 112(13): 2061-75. doi: 10.1161/CIRCULATIONAHA.105.169251

24. Ludwig DS, Peterson KE, Gortmaker SL. Relation between consumption of sugar-sweetened drinks and childhood obesity: a prospective, observational analysis. Lancet. 2001; 357: 505-508.

\section{УДК 612.3-057.874=111}

\section{АНАЛІЗ СОМАТОТИПІВ ТА ХАРЧОВОЇ ПОВЕДІНКИ ШКОЛЯРІВ 12-15 РОКІВ}

\section{Бегалія Мохамед, Насер Абделькадер, Буфаден Отман, Белгріссі Абдельхамід}

Резюме. Стадія підліткового віку - це стадія, на якій на життя молодої людини впливають фрізіологічні чинники, які залежать від індивідуальної генетики, клімату та природи. Фізичне зростання на цій стадії характеризується швидкістю і дисбалансом, так як тіло росте дуже швидко і нерівномірно. Ця стадія характеризується зміною зросту і ваги, що відбивається на ширині плечей і грудей, довжині тулуба, окружності сідниць і довжині ніг. Фізичне зростання досягає максимальної швидкості в віці 12 років у дівчаток, і 14 років у хлопчиків.

В даному дослідженні взяли участь учні школи у віці 12-15 років. Дослідження проводилося на вибірці з 70 учнів (32 дівчинки і 38 хлопчиків), які були відібрані випадковим чином із 355 учнів школи. Були використані антропометричні вимірювання, за допомогою яких були визначені відсоток маси тіла та моделі тіла. Для визначення впливу харчування, протягом місяця відстежували харчову поведінку досліджуваної вибірки і записували склад їжі (сніданок, обід і вечерю за останній день плюс інший випадковий час).

Дослідження показало, що м'язова маса пропорційна харчовій поведінці. Відсотковий вміст м'язової маси є найвищим серед інших співвідношень, так як він знаходився в межах від 42,25\% (хлопчики) до 56,03\% (дівчата), кісткова маса - 20,53\% (хлопчики) і 25,19\% (дівчинки) і маса жиру - 8,29\% (хлопчики) і 11,01\% (дівчата). Результати показали, що кількість продуктів, багатих на вуглеводи, визначає щоденний раціон. Середня кількість прийомів їжі протягом місяця оцінювалася в 84,75\% за рахунок вживання великої кількості хліба, кускусу і макаронних виробів. Як зростання, так і вага були прямо пропорційні віку, і при відстежуванні зміни зростання в віці від 6 до 15 років встановлено, що вміст холестерину і 
тригліцеридів був пропорційним. Масове співвідношення холестерину в крові було в межах $[1,09-1,58]$ г/л, а співвідношення тригліцеридів - у межах $[0,78-1,02]$ г/л.

Проаналізувавши результати, а також аналогічні дослідження, дійшли висновку, що м'язова маса $€$ домінуючою для досліджуваної вибірки в порівнянні з кістковою і жировою масою зазначеного контингенту і віку.

Ключові слова: соматотип, харчування, антропометрія, школярі.

Удк 612.3-057.874=111

АНАЛИЗ СОМАТОТИПОВ И ПИЩЕВОГО ПОВЕДЕНИЯ ШКОЛЬНИКОВ 12-15 ЛЕТ

Бегалия Мохамед, Насер Абделькадер, Буфаден Отман, Белгрисси Абдельхамид

Резюме. Стадия подросткового возраста - это стадия, на которой на жизнь молодого человека влияют фризиологические факторы, зависящие от индивидуальной генетики, климата и природы. Физический рост на этой стадии характеризуется скоростью и дисбалансом, так как тело растет очень быстро и неравномерно. Эта стадия характеризуется изменением роста и веса, что отражается на ширине плеч и груди, длине туловища, окружности ягодиц и длине ног. Физический рост достигает максимальной скорости в возрасте 12 лет у девочек и 14 лет у мальчиков.

В данном исследовании приняли участие учащиеся школы в возрасте 12-15 лет. Исследование проводилось на выборке из 70 учеников (32 девочки и 38 мальчиков), которые были отобраны случайным образом из 355 учеников школы. Были использованы антропометрические измерения, с помощью которых были определены процент массы тела и модели тела. Для определения влияния питания, в течение месяца отслеживали пищевое поведение исследуемой выборки и записывали состав еды (завтрак, обед и ужин за последний день плюс другое случайное время).

Исследование показало, что мышечная масса пропорциональна пищевому поведению. Процентное содержание мышечной массы является самым высоким среди других соотношений, так как оно находилось в пределах от 42,25\% (мальчики) до 56,03\% (девочки), костная масса - 20,53\% (мальчики) и 25,19\% (девочки) и масса жира - 8,29\% (мальчики) и 11,01\% (девочки). Результаты показали, что количество веществ, богатых углеводами, определяет ежедневный рацион. Среднее количество приемов пищи в течение месяца оценивалось в $84,75 \%$ за счет употребления большого количества хлеба, кускуса и макаронных изделий. Как рост, так и вес были прямо пропорциональны возрасту, и при отслеживании изменения роста в возрасте от 6 до 15 лет установлено, что содержание холестерина и триглицеридов было пропорциональным. Массовое соотношение холестерина в крови было в пределах $[1,09-1,58]$ г/л, а соотношение триглицеридов - в пределах $[0,78-1,02] г / л$.

Проанализировав результаты, а также аналогичные исследования, был сделан вывод, что мышечная масса является доминирующей для исследуемой выборки по сравнению с костной и жировой массой указанного контингента и возраста.

Ключевые слова: соматотип, питание, антропометрия, школьники.

The authors of this study confirm that the research and publication of the results were not associated with any conflicts regarding commercial or financial relations, relations with organizations and/or individuals who may have been related to the study, and interrelations of coauthors of the article. 